\title{
International Risk Tolerance, Capital Market Failure and Capital Flows to Emerging Markets
}

\author{
Valpy FitzGerald*
}

April 2006

\begin{abstract}
The level, tenor and instability of capital flows from global financial markets towards developing countries are a major source of concern for macroeconomic managers, while their causes remain largely unexplained by economic theory. Country 'fundamentals' (such as economic growth, monetary stability and institutional capacity) as sources of default risk have been the main focus of economic research and policy prescriptions. However, recent empirical research on the determinants of capital flows and the roots of market failure indicate that much of the explanation lies in the nature of the home (that is, the developed country) demand for emerging market assets. In this paper, the microeconomic roots of home bias and demand instability are explained in terms of investor risk perception and credit rationing, exacerbated by traders' behaviour. The consequences for host country macroeconomic balances and income distribution .../
\end{abstract}

Keywords: asset demand, international finance, capital flows, emerging markets, financial stability, home bias, risk tolerance

JEL classification: F21, F32, F33, G15, O19

Copyright (c) UNU-WIDER 2006

*Department of International Development, University of Oxford

This study is a revised version of the paper presented at the 17-18 June 2005 UNU-WIDER anniversary conference, 'WIDER Thinking Ahead: The Future of Development Economics', directed by George Mavrotas and Anthony Shorrocks.

UNU-WIDER gratefully acknowledges the financial contributions to the research programme by the governments of Denmark (Royal Ministry of Foreign Affairs), Finland (Ministry for Foreign Affairs), Norway (Royal Ministry of Foreign Affairs), Sweden (Swedish International Development Cooperation Agency_Sida) and the United Kingdom (Department for International Development). 
of varying investor risk tolerance are then demonstrated. Although the net impact also depends upon the host policy response, this transmission mechanism means that host 'fundamentals' are themselves strongly affected by capital flows and thus cannot be considered as to be independent of home asset demand. The paper concludes by examining the implications of these findings for the future of development economics in general and for policy response in particular.

\section{Acknowledgements}

I am very grateful to colleagues at the Helsinki conference in June 2005, and to the anonymous UNU-WIDER referees, for their constructive criticism.

The World Institute for Development Economics Research (WIDER) was established by the United Nations University (UNU) as its first research and training centre and started work in Helsinki, Finland in 1985. The Institute undertakes applied research and policy analysis on structural changes affecting the developing and transitional economies, provides a forum for the advocacy of policies leading to robust, equitable and environmentally sustainable growth, and promotes capacity strengthening and training in the field of economic and social policy making. Work is carried out by staff researchers and visiting scholars in Helsinki and through networks of collaborating scholars and institutions around the world. www.wider.unu.edu publications@wider.unu.edu

UNU World Institute for Development Economics Research (UNU-WIDER)

Katajanokanlaituri 6 B, 00160 Helsinki, Finland

Camera-ready typescript prepared by Lorraine Telfer-Taivainen at UNU-WIDER

The views expressed in this publication are those of the author(s). Publication does not imply endorsement by the Institute or the United Nations University, nor by the programme/project sponsors, of any of the views expressed. 


\section{Introduction}

For the past two decades as capital market financing1 for middle-income developing countries, now known as 'emerging markets', has expanded enormously, so has the academic literature on the explanations for the evident instability of these flows to and their allocation across these host countries. Most of this literature and the policy debate have centred on macroeconomic stability, market access and institutional arrangements in emerging market economies themselves - that is, on host 'fundamentals'. Much less attention has been paid by development economists to the nature of the demand schedule, in terms of both level and stability, or emerging market assets on the part of international investors, and in particular the role of 'home' market factors in the developed economies. In marked contrast, the professional or 'market' literature, including that written by regulators, takes these demand shifts very seriously (FitzGerald 2003).

Shifts in global demand (principally from G3 banks and institutions) for emerging market assets and accompanying characteristics of home market behaviour, account for a major part of the instability in capital flows shown in Figure 1. The present consensus is that about one half of flow variation is accounted for by the 'push' factors, but when market interactions are taken into account the net effect of home factors turns out to be rather higher. ${ }^{2}$ In addition, the maturity of debt securities is generally quite short, generating large fluctuations in capital flows in response to temporary changes in home market sentiment.

Figure 1: Emerging market financing (US\$ billion)

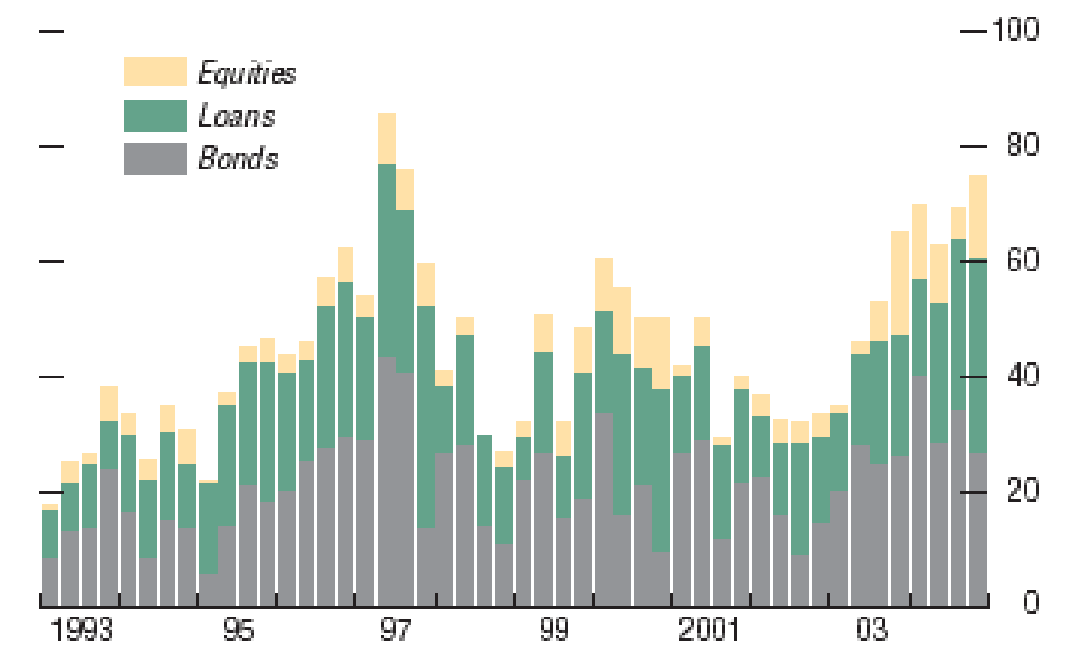

Source: IMF Global Financial Stability Report, April 2005.

1 As is customary, I exclude foreign direct investment (FDI) as these are intra-firm asset/liability transactions within multinational enterprises, and thus not market flows by definition.

2 See IMF (2001) and Section 2 of this chapter. 
What is more, emerging market securities account for less than one per cent of the total G3 portfolio. This low overall level of investment in the emerging market asset class as a whole cannot be simply attributed to poor risk-return characteristics. As Figure 2 shows, emerging market debt has a risk level lying between those of OECD bonds and equities, and a rate of return higher than either. Emerging market equity has on average better returns and lower risk than OECD equity. Indeed it is well established that there is strong and pervasive home bias against all foreign assets among portfolio investors.

Figure 2: Risk-return tradeoff (\%)

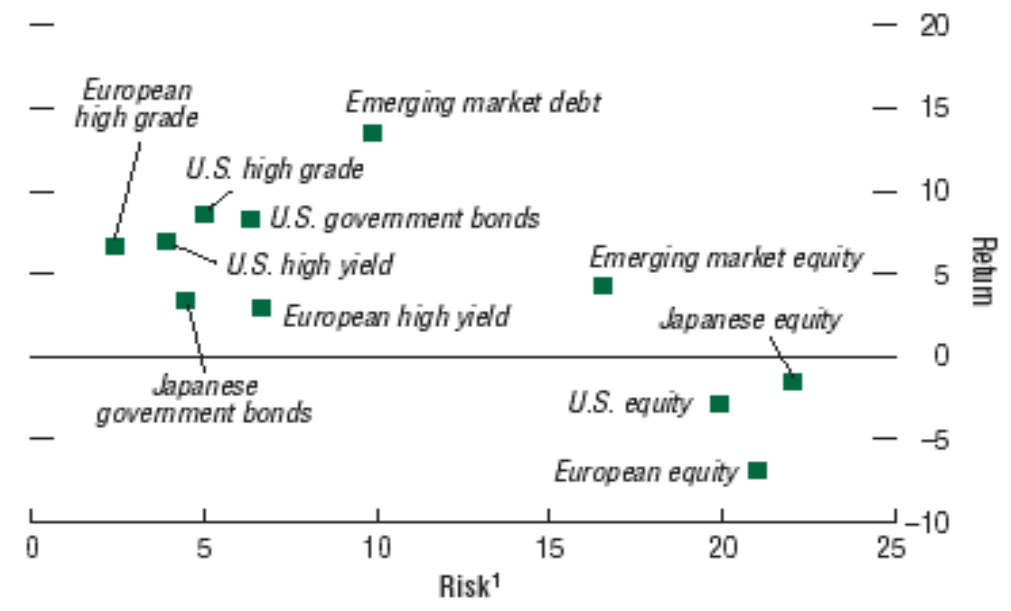

Source: IMF Global Financial Stability Report, April 2005.

Recent research on the determinants of capital flows and the causes of this market failure are surveyed in Section 2 of this chapter. In Section 3, the microeconomic roots of home bias and demand instability are explained in terms of investor risk perception and credit rationing, exacerbated by trader behaviour. Section 4 demonstrates the impact of these flows on host macroeconomic balances and income distribution. Although the net impact also depends upon the host policy response, this transmission means that host 'fundamentals' are themselves strongly affected by capital flows and thus cannot be considered as to be independent of the push factors. Section 5 concludes by examining the implications of these findings for the future of development economics in general and for policy response in particular.

\section{Recent research on home demand for emerging market assets}

Home interest rates, home asset price volatility, covariance with emerging market assets and risk tolerance clearly affect demand for emerging market assets (Disyatat and Gelos 2001). The standard model used in the empirical literature 3 states that the portfolio

3 See Jeanneau and Micu (2002) for an excellent survey of the empirical literature. However, analytical modelling has made little progress since Dumas (1994) pointed out that international capital markets theory does not approximate the real world in a useful way. 
capital flow from any one country of origin to a country of destination is the result of push and pull factors: two separate vectors for capital supply and 'country risk/return characteristics' are assumed to exist and interact to produce the observed volume (capital flow) and price (yield spread). Push factors in these models conventionally include: home country wealth (for example, GDP); home monetary policy (for example, money supply); riskless home interest rate (for example, US treasury yield); and home asset risk (for example, US bond yield spread). The empirical literature (see Montiel and Reinhart 2001) indicates that roughly half of the observed flow variance can be explained by these factors. Pull factors usually include: emerging market sovereign bond yield spreads; risk ratings as measures of creditworthiness; host country growth rates and debt levels, and so on. Montiel and Reinhart (1999) employ fixed-effects panel data analysis for 15 emerging market countries and examine the volume and composition of capital inflows. They conclude that international interest rates have an important effect on not only the volume but also the asset composition of flows. Mody et al. (2001) use a vector equilibrium correction model to forecast pull and push factors for inflows to 32 developing countries and conclude that in general common push factors are determinant in short-run dynamics even though pull factors are more important in the long-run allocation of aggregate flows to particular countries. 4

Taylor and Sarno (1997) examine the determinants of US portfolio capital outflows towards Latin America and Asia using cointegration techniques. They find that global (push) and domestic (pull) factors have similar importance in explaining short-run equity flows to Asia and Latin America. However, for the short-run dynamics of bond flows, global factors (particularly USA interest rates) are found to be more important than domestic factors. Chuhan et al. (1998) model USA portfolio flows to Latin American and Asian markets using panel data method. They too find that push factors are the main determinants of portfolio flows to Latin America and Asia, although equity flows are more sensitive to global factors than bond flows, which are more sensitive to credit ratings and secondary market debt prices.

Although there are good reasons to believe that the international market for emerging market assets is 'credit rationed' (see Section 3), only Mody and Taylor (2002) have so far made this explicit in an innovative disequilibrium model: using a maximum likelihood estimation technique they estimate the probability of the demand for capital exceeding supply for emerging markets and find that the push effect dominates, especially in times of 'capital crunches'. A separate literature on the determination of emerging market bond spreads on primary issues justifies this approach, because it clear that home as well as host characteristics affect spreads (Fernández-Arias 1996). In consequence, FitzGerald and Krolzig (2003, 2005a) address the estimation of the aggregate international demand schedule for emerging market bonds as a single asset

4 However, they treat bond yields as an exogenous variable, implicitly assuming that yields are unaffected by the capital flows themselves: this may lead to an underestimation of the strength of asset demand fluctuations. 
class, using a simultaneous-equation estimation model. We find that not only do spreads affect flows, but also that flows affect spreads (as might be expected in a rationed credit market) and that lagged spreads and flows have a similar effect-indicating that market behaviour such as investor herding and momentum trading are also significant. Our main finding is that over three-quarters of the observed variation in aggregate bond flows to emerging markets can be attributed to shifts in the demand schedule and endogenous market interactions. 5 Home market factors not only strongly influence the volatility of flows but also seem to determine their relatively low level: the proportion of foreign assets in home investment portfolios tends to be very small compared to the efficient portfolio theory prediction for observed risk (volatility) and return.6 Administrative or regulatory barriers to international investment cannot explain this as these have been significantly lowered in recent years (Ahearne et al. 2001) ${ }^{7}$ and the risk premium has not fallen to reflect diversification gains (Bekaert and Harvey 2000; Henry 2000).

An alternative approach to explaining home bias is to suggest that information is asymmetric: home investors know less about host than home stocks. It is certainly the case that foreign securities issues or quoted on home markets suffer less from home bias (Ahearne et al. 2001). However, institutional investors who make up most of overseas investment generally do better in host markets due to scale economies in research (Grinblatt and Keloharju 2000). To attempt to redefine changing risk tolerance as variations in risk perception does not really serve, for this version of asymmetric information theory does not allow for the large fluctuations in home bias observed independently of the underlying real risk, and would make research into emerging markets extremely profitable leading in turn to rapidly decreasing home bias over time. Potentially more promising is a Bayesian approach where the investor has prior views about means and returns, updates these views as she observes new data and then makes the portfolio allocation decisions (Klein and Bawa 1977). However, numerical simulation of this process indicates that only if the investor holds implausible prior

5 This model is extended in FitzGerald and Krolzig (2005b) to a two-stage procedure of portfolio allocation: first to emerging markets as an asset class and then to individual host countries according to their risk-return fundamentals. This model was successfully tested on US purchases of bonds issued by Argentina, Brazil, Korea and Mexico, using a similar econometric methodology.

6 French and Poterba (1991) and Tesar and Werner (1995) show that in the early 1990s (that is, at the start of the period considered in this paper) stock market wealth was invested more than 90 per cent in the domestic market by the USA and Japan, and more than 80 per cent by the UK and Germany. These shares were far less than the share of domestic equity markets in world equity markets. Indeed in the US international equity had been less than 1 per cent of financial assets in the three post-Second World War decades. Only after 1985 holdings of foreign stocks increased sharply to roughly 10 per cent. Interestingly, this share has been relatively stable since then: 10 per cent in 1994 and 11 per cent in 2001 (Karolyi and Stulz 2002).

7 Similarly home bias might be attributed to host withholding taxes on foreign investment income that cannot be offset against home taxes. However, Cooper and Kaplanis (1994) and French and Poterba (1991) find that the observed degree of home bias could only be explained by implausible differences in effective taxation of foreign investments. 
views can home bias be generated; while an investor with diffuse prior views about foreign returns would arrive an allocation not far from the optimal (Lewis 1999). An asymmetric risk function, with losses valued more highly than gains, may reflect investor behaviour better too, but this does not explain home bias either. 8

So the equity home bias puzzle remains and is even stronger for emerging markets than for overseas equity as a whole. Moreover, most of the literature refers to US institutional investors but this is also true of UK institutions, which are under few constraints in this regard (Blake and Timmermann 2000; Blake et al. 1999). In consequence Babilis and FitzGerald (2005) used data on UK pension fund portfolios and the standard theoretical model (see next section) to measure home bias by UK pension funds. We find that this bias is doubly acute in the case of emerging market equity - a bias against overseas assets as a whole being further magnified by a bias against emerging markets within the foreign equity class as a whole. Even more interestingly, the bias varies over time as Figure 3 indicates, with home bias (as defined the Technical Appendix) varying from -20 per cent to +80 per cent over a few years. Froot and O'Connell (2003) take a similar approach in comparing the equity portfolios of global and local investors, showing that relative risk tolerance of the latter varies widely and cyclically over time. There is good reason to suppose, therefore, that risk tolerance varies over time and possibly (in view of the shape of the graph in Figure 3 and its association with the Latin American and East Asian crises) that it is path-dependent.

Figure 3: Home bias against emerging market equity by UK pension funds

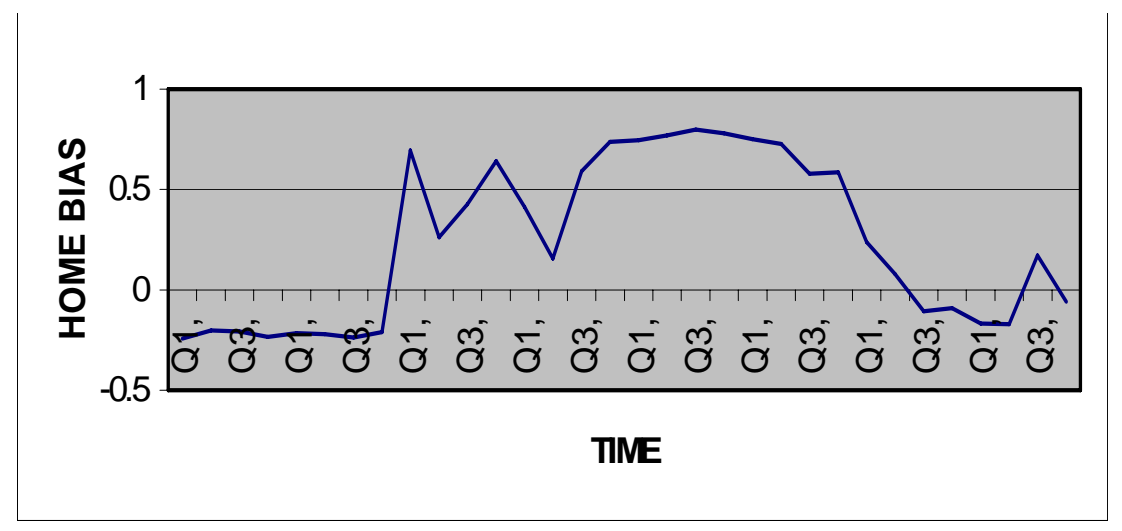

Source: Babilis and FitzGerald (2005).

\section{Risk tolerance and credit rationing in the market for EM assets}

The microeconomic foundation for the analysis of the aggregate demand for EM assets is to be found in portfolio theory. Consider a world where home investors hold assets

8 For instance, Siegmann (2003) takes both a traditional risk measure and a downside risk measure and analyzes the outcomes as a function of the initial conditions. Higher uncertainty moves the optimal policy 'to the right' (that is, the minimum risk allocation is attained at higher wealth levels) and thus would reduce the overseas equity share in the efficient portfolio for any given risk tolerance. 
from the home economy $(h)$ and emerging markets $(f)$. The stock $\left(A_{f}\right)$ of these EM assets is a proportion $\left(x^{f}\right)$ of the wealth $\left(W_{h}\right)$ of the home portfolio holder

$$
A_{f}=W_{h} x^{f}
$$

Standard portfolio optimization theory (see Appendix) yields the efficient portfolio share $\left(x^{f}\right)$ for the representative investor faced with a given set of expected returns $\left(E_{t} r_{t+1}\right)$

$$
x_{t}^{f}=\frac{\left(E_{t} r_{t+1}^{f}-E_{t} r_{t+1}^{h}\right) / \gamma}{\operatorname{Var}\left(r^{f}-r^{h}\right)}+\frac{\sigma_{h}^{2}-\sigma_{h f}}{\operatorname{Var}\left(r^{f}-r^{h}\right)}
$$

where $\gamma$ is the parameter of relative risk aversion, $\sigma_{h}^{2}$ is the variance of home asset returns, $\sigma_{f}^{2}$ is the variance of EM asset returns and $\sigma_{h f}$ is the covariance between home and host returns.

The first term of the right hand side of equation (2) can be interpreted as the demand for EM assets: higher expected returns raise demand while a higher variance of returns has the opposite effect. As home investors' degree of risk aversion $(\gamma)$ increases, demand falls: note that this effect is multiplicative with risk (variance). The second term in equation (2) is the portfolio share that minimises the variance of the wealth portfolio. The key point here is that the demand for emerging market assts will clearly depend not only upon host 'fundamentals' that determine risk-return characteristics (that is, $r_{f}$ and $\sigma_{f}^{2}$ ) but also upon variables in the home market such as risk aversion, home volatility $\left(\sigma_{h}^{2}\right)$ and the covariance between home and EM assets $\left(\sigma_{h f}\right)$.

Given a set of observed returns, variances and covariances home bias is the difference between $x^{f}$ and the observed portfolio share, as we have seen. The only unobserved variable is risk aversion $\gamma$, which is normally set at unity in estimating home bias empirically. However the extent and variability of home bias does seem to support the case for considering it to be a variable that changes over time in response to recent events, reinforced by endogenous market characteristics related to fund managers' behaviour. It is thus necessary to posit an explicit model of risk aversion —or its inverse, 'risk tolerance' or 'risk appetite' as it is known by market participants.

Kumar and Persaud (2001) argue that most of the indicators used to proxy risk tolerance in the literature confuse the level of risk itself with risk tolerance: asset prices (or yield spreads) are in practice a function of both underlying risk and risk tolerance, this latter containing structural components (the underlying utility function and financial market structure) and a time varying element reflecting shorter-term factors such as so-called 
'wake up calls'.9 When these result from major collapses in emerging markets (such as the 1998 Russian crash), the effect on home risk appetite then affects other emerging markets through what is known as 'pure' contagion. The sudden shifts in risk tolerance associated with these wake up calls also reflect abrupt portfolio adjustments asset prices reach the limits of what is considered normal by the market; what de Grauwe terms a 'band of agnosticism', within which the gains from portfolio allocation are not large enough to justify the transactions costs of optimization and thus reflects 'rational behaviour in an uncertain world' (de Grauwe 1996: 181-206).

A change in risk aversion on the part of the market as a whole will, of course, affect the returns on EM assets themselves as well as the flows, as the risk premium will rise. Leaving aside covariance issues for simplicity of exposition, the 'yield spread' $\left(s_{f}\right)$ of EM returns over a riskless home asset will be determined by the process of arbitrage such that asset prices adjust to the point where

$$
\begin{aligned}
& r^{f}=r^{h}+\gamma \sigma_{f}^{2} \\
& s_{f}=r^{f}-r^{h}=\gamma \sigma_{f}^{2}
\end{aligned}
$$

In other words the yield spread is equal to the risk premium. However, this in turn is the product of home risk aversion and host risk: with the additional feature that the larger the risk on any one EM asset, the more it its risk premium will rise for a given increase in risk aversion even though the underlying risk itself has not changed. This would help explain the 'double home bias' (against foreign assets, and within this, even more against EM assets) that we have discussed in the previous section. This also reinforces the point made in the previous section, that EM asset returns are not only determined by host fundamentals but also by home factors. In other words, pull factors cannot be fully separated from push factors.

Further, the level of risk in EM assets is essentially that of default or devaluation (if they are denominated in local currency) and this clearly increases with the level of indebtedness. In addition, higher spreads mean increased debt service costs, again increasing the probability of default. There thus emerges a process of credit rationing similar to that characterized by uncertainty in the loan market. Adverse selection arises because the two sides have different perceptions of risk and lenders cannot distinguish fully between borrowers. As in the international bank lending model of Folkerts-Landau (1985), the supply schedule for capital (that is, the demand schedule for EM assets in our case) will be backward-sloping beyond a certain point as shown in Figure 310 - in consequence, the market may not clear. In other words, the equilibrium is not the point

9 Kumar and Persaud (2001) estimate risk appetite by calculating excess returns (the difference between spot rates and forward rates from the previous period) on seventeen emerging market currencies over ten years. Their risk appetite index exhibits marked quarterly and annual cycles, and troughs that appear to be correlated with major market discontinuities.

10 For the derivation, see Appendix. 
where the demand and supply schedules intersect; and some borrowers are unsatisfied at the equilibrium interest rate. 11 Under these circumstances it is clear that a change in risk tolerance by lenders will bring about horizontal shift in the capital supply schedule. In other words, high yield spreads will be associated with low capital flows, which is in fact the case as we have seen in the previous section.

Figure 4: Credit rationing in emerging market assets

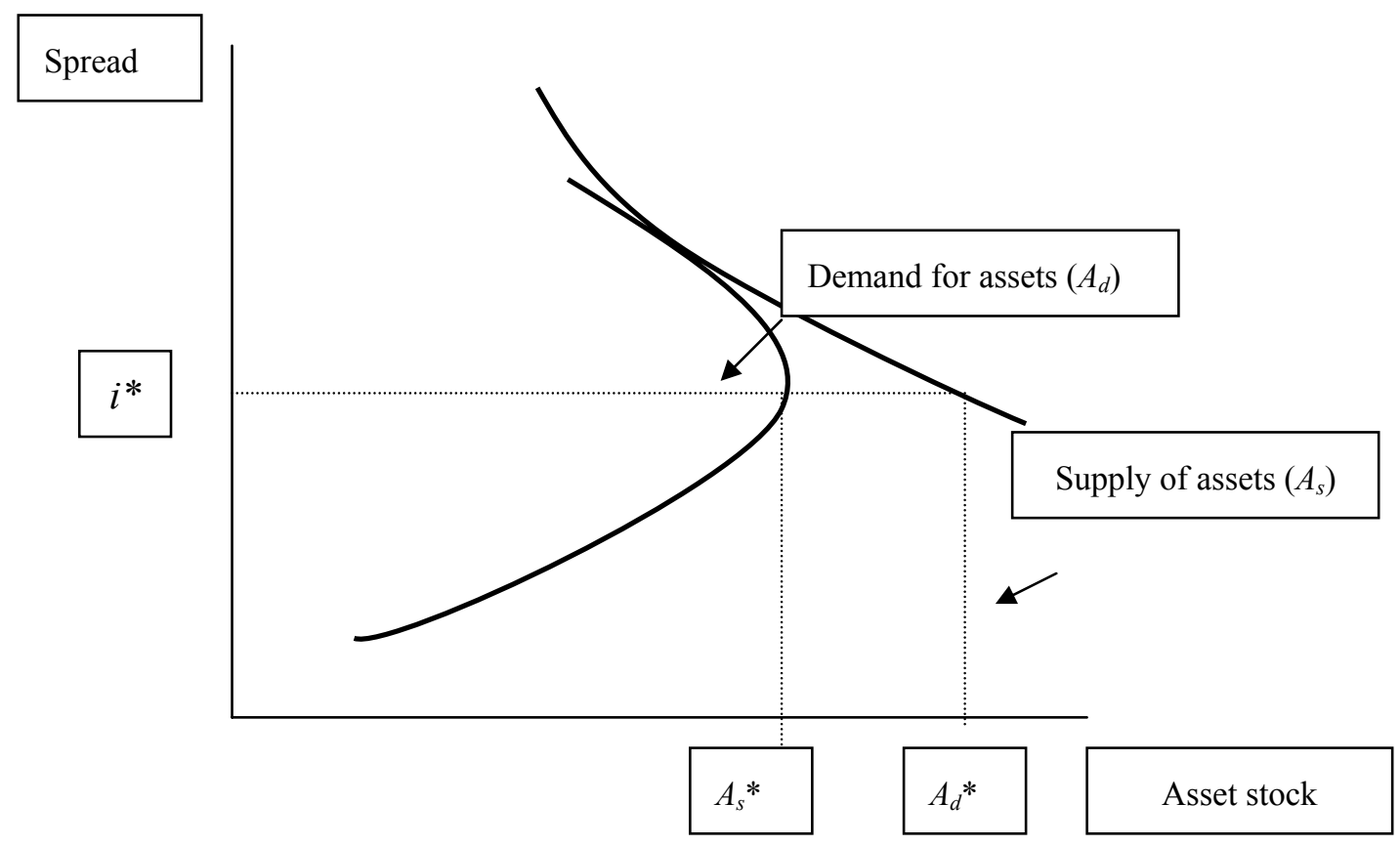

\section{The implications of volatile emerging market asset demand for macroeconomic stability in developing countries}

This instability in capital flows and spreads, originating in 'home' financial markets, has profound consequences for host economies themselves; particularly since small open emerging markets are increasingly driven by the capital account. This is for at least three reasons. First, because the interest rate is effectively set externally. Second, because the level of investment and the long-run capital stock is determined in relation to global capital markets. Third, because the short-run level of output is affected by the level of bank credit and import availability; and fourth because the real exchange rate (and thus both export incentives and the real wage rate) is the result of capital flows. And in each case, investor risk tolerance is crucial in determining the outcome.

11 Of course the aggregate will be made up of all emerging markets, some of which (for example Taiwan Chile) have permanent access and others who can only enter the market when investor sentiment permits. 
With a liberalized capital account, arbitrage will ensure that uncovered interest rate parity obtains. In other words, the domestic interest rate $\left(i_{d}\right)$ is necessarily equal to the sum of the world interest rate $\left(i_{\S}\right)$, the expected rate of depreciation of the nominal exchange rate $(\dot{E})$ and the default risk premium $(\rho)$; where of course this premium is the product of the default risk $(p)$ itself and the risk aversion parameter $(\gamma)$ as we have seen in the previous section 12

$$
\begin{aligned}
& i_{d}=i_{\$}+\dot{E}+\rho \\
& \rho=\not p
\end{aligned}
$$

In other words, the domestic interest rate is no longer determined by the balancing of domestic investment and domestic saving, but rather by the capital account. An important consequence is that any increase in the home interest rate $\left(i_{\S}\right)$ or home risk aversion $(\gamma)$ will immediately increase the host interest rate $\left(i_{d}\right)$ and thus tighten the monetary stance in the short run and reduce the investment rate in the long. We can assess the long-run effect of this arbitrage as follows. Consider an economy with a familiar production function where output capacity $(Y)$ depends on the stock of capital $(K)$ and labour $(L)$. The host rate of return on capital $\left(r_{f}\right)$ must equal the rate of return in the home economy $\left(r_{h}\right)$ plus the risk premium before, which solves for the level of output per worker $(y)$

$$
\begin{aligned}
& Y_{f}=B_{f} K_{f}^{\alpha} L_{f}^{1-\alpha} \\
& r_{f}=\frac{\partial Y_{f}}{\partial K_{f}}=\alpha B_{f}\left(\frac{K_{f}}{L_{f}}\right)^{\alpha-1} \\
& r_{f}=r_{h}+\not p \\
& y=\frac{Y_{f}}{L_{f}}=\left(\frac{\alpha B_{f}}{r_{h}+\not p}\right)^{\frac{\alpha}{1-\alpha}}
\end{aligned}
$$

In other words, any increase in the home interest rate $\left(i_{\S}\right)$ or home risk aversion $(\gamma)$ will depress the long-run level of income per capita $(y)$ in the host economy.

In the short run, within a given long-run capacity (which depends on investment), output $(Q)$ will be constrained by credit supply_itself affected by bank liabilities and thus foreign borrowing - or else foreign exchange availability as the authorities regulate aggregate demand in order to ensure that reserves are not depleted. Consider a simple linear balance of payments model with exports $(X)$, imports $(M)$ and capital flows $(F)$. Exports are a function of world demand $(Z)$ and the real exchange rate $(e)$; and imports

12 Formally, the risk premium is only equal to the underlying default risk if the financial market is strictly risk-neutral and there is perfect information. 
of domestic output $(Q)$ and the real exchange rate. Finally, reserves $(R)$ are maintained at a target proportion $(\varphi)$ of external liabilities.

$$
\begin{aligned}
& X=x_{1} Z+x_{2} e \\
& M=m_{1} Q-m_{2} e \\
& \Delta R=\varphi F \\
& X+F \equiv M+\Delta R
\end{aligned}
$$

We assume here that the government maintains a target real exchange rate $\left(e^{*}\right)$ in order to maintain export competitiveness. In this case, output $(Q)$ becomes a function of the capital flow - and by extension the home factors we have discussed before-home investor wealth, return on home assets and home risk aversion. In particular, an increase in home risk will reduce capital flows and thus emerging market output. Rearranging equation 6 gives $Q$ in terms of $F$

$$
\begin{aligned}
& Q=\left\{F+x_{1} Z+e^{*}\left(x_{2}+m_{2}\right)\right\} / m_{1} \\
& \partial Q / \partial F=1 / m_{1}>0
\end{aligned}
$$

In other words, there is a very strong multiplier effect of capital flows on output, because the reciprocal the import coefficient $\left(m_{1}\right)$ has a value between 0.2 and 0.3 for most emerging markets: so that a capital (outflow) equivalent 13 to 3 per cent of host GDP causes output to rise (fall) by up to 15 per cent.

Alternatively, if output itself is targeted by the authorities then the real exchange rate adjusts to capital flows - and by extension the same home factors mentioned above. An inflow leads to currency appreciation (that is, $e$ falling) and must also mean a real wage increase and vice versa (see Appendix). The fact that overvaluation from capital inflows is politically popular among organized workers and consumers, and undervaluation resulting from outflows unpopular, is merely a reflection of this distributional logic. However, if real wages are to be stabilized, and thus the real exchange rate, then employment will fluctuate with output as in equation (7) and this will prejudice those at the margin of the formal sector labour force, who are likely to be the poorer ones. 14

Moreover, whether the level of output or the real exchange rate is targeted, the implications for real investment levels as a whole are ambiguous because the former affects aggregate demand (and thus profit expectations) while the latter affects the allocation of investment between traded and non-traded sectors if the real exchange rate

13 See Table 1 and the discussion in Section 5.

14 The research literature on the economics of child welfare suggests that wages both constitute the major component of the incomes of poor families and affect the division of labour within the household. But from the viewpoint of children, the crucial aspect is whether the head of the household is in steady employment and forced to seek work away from the home; that is, in stable employment albeit at low wages (FitzGerald 2001b). 
is allowed to fluctuate (FitzGerald and Perosino 1999). Last but not least, investment is negatively affected by output or profit rate volatility due to the hysteresis arising from irreversibility of fixed capital formation (FitzGerald 2001a). This is not to suggest that these capital flows necessarily have a negative effect on growth, and certainly could make a greater contribution were home bias to be less pronounced, but rather that the potential for macroeconomic instability is soundly based on economic theory.

\section{Conclusions: international capital market failure and the future of development economics}

In this stuy I have argued that the low level of capital flows to emerging markets and their instability are both largely due to the nature of the asset demand schedule for home investors, independently of the underlying quality of those assets ('fundamentals'). The same is undoubtedly true of the short 'tenor' of these investments, although I have not addressed this directly. Indeed the greater part of aggregate shifts in the demand emerging market assets can be attributed to events in the home capital markets: changes in risk tolerance and investor confidence as well as shifts in interest rates and wealth levels on the one hand, and trading behaviour in the form of herding and momentum trading on the other. This is not just a theoretical issue, because the macroeconomic and distributional consequences for emerging markets are disproportionately large: they are in effect a major externality. 15

The practical significance of this externality results from the asymmetry in international capital markets: while these flows are relatively small in relation to home economies, they are very large relative to host markets - as Table 1 illustrates. Total emerging market capitalization (including all developing countries) is a very small part of the world total, and their ratio of market capitalization to GDP is far less than that for advanced economies. In consequence, a specific level of capital flow is ten times larger relative to the size of the host market compared to the home market. Thus capital market shocks will be transferred from home to host countries in a very asymmetric fashionshocks which the narrow and shallow host capital markets find very difficult to adsorb.

Nonetheless, the extent of home bias means that the situation in Table 1 is very far from equilibrium. The international version of the standard asset pricing model suggests that to maximize risk-adjusted returns investors should hold the world market portfolio of risky assets, irrespective of their country of residence. Under a number of assumptions about market efficiency (particularly that risk is fully reflected in price and thus return), the weighting of a country's assets within the portfolio should therefore reflect the weighting of the market capitalization of that country in the world market capitalization

15 Interestingly, this was the position taken by the IMF in the World Economic Outlook for 1998 ('Financial Crises: Characteristics and Indicators of Vulnerability'), although by 2005 the World Economic Outlook had become much more sanguine, attributing most of emerging market volatility to domestic fundamentals. 
(Ahearne et al. 2001). From the data in Table 1, this implies that advanced economy investors should hold approximately one tenth of their portfolio in emerging market assets, but in reality it is roughly one hundredth.

Table 1: World market capitalization (US\$ billion)

\begin{tabular}{lrrrrrrr}
\hline & $\begin{array}{r}\text { Stock market } \\
\text { cap. }\end{array}$ & $\begin{array}{r}\text { Debt } \\
\text { securities }\end{array}$ & $\begin{array}{r}\text { Bank } \\
\text { assets }\end{array}$ & Total & GDP & \\
\hline & A & B & C & D=A+B+C & E & F=D/E \\
$\begin{array}{l}\text { Market } \\
\text { capitalization }\end{array}$ & 27855 & 48236 & 39759 & 115250 & 27863 & $413.6 \%$ \\
$\begin{array}{l}\text { Advanced } \\
\text { economies }\end{array}$ & 3947 & 3069 & 8075 & 15091 & 8457 & $178.4 \%$ \\
$\begin{array}{l}\text { Emerging markets } \\
\text { World total }\end{array}$ & 31802 & 51305 & 47834 & 130341 & 36320 & $358.9 \%$ \\
& & & & & & & \\
& Equities & Bonds & Loans & Total & & & \\
EM Financing & & & & & & & \\
Total & 43 & 132 & 105 & 280 & & \\
\% AE Mkt Cap & 0.2 & 0.3 & 0.3 & 0.2 & & \\
\% EM Mkt Cap & 1.1 & 4.3 & 1.3 & 1.9 & & \\
\hline
\end{tabular}

Source: IMF Global Financial Stability Report 2005, and author's calculations.

There is, in consequence, a major externality to be addressed. The First Theorem of welfare economics argues that a Pareto efficient competitive equilibrium is reached where three conditions obtain.16 First, households and firms must act in perfect competition. Second, there is a full set of markets, particularly for futures and risk bearing. Third, there is perfect information. Thus market failure may occur even if firms and households behave in a perfectly competitive manner because the second and third conditions are unlikely to hold, and the market equilibrium, if it exists, is not welfare maximizing. The second condition usually fails to obtain in emerging markets because in many cases only spot prices exist and there are few homogeneous future options. 17 The third condition also usually fails to obtain because information is imperfect and costly to acquire, and usually proprietary in consequence. Further, the widespread presence of externalities and the public goods nature of certain investments often prevent investors in emerging markets capturing the full value of asset prices and discourage them from financing these projects.

Investors in emerging markets face a particular variant of market inefficiency: difficulties of contract enforcement (that is, debt default) and thus asset valuation

\footnotetext{
16 See Atkinson and Stiglitz (1980).

17 Let alone the complete Arrow-Debreu set for all possible states of the world assumed in say, Obsfeld and Rogoff (1996).
} 
caused by the lack of an international legal system support creditors. 18 However, at the root of two of the most discussed problems lies the problem of investor uncertainty: unobservable outcomes (for example, contractual default) and unobservable behavior (for example, moral hazard). Banks' own limits on lending for fear of default can also promote liquidity crises as well as the credit rationing discussed in Section 3, as no further lending may be available even though borrowers are solvent. Further, there are 'missing markets' for securities issued by many poor countries and for long-term bank loans to these countries. Markets for long-term bonds do not exist for most middleincome countries either.

Nonetheless, the potential gains from improved information should not be overestimated. International institutions and emerging market regulators have made considerable progress in augmenting and improving the flow of information to investors, yet there is little evidence that this information is much used. Partly this is an issue of timeliness - which is why relatively simple indicators such as the quick ratio 19 are still popular-but also, and more interestingly, one of the heuristic models that investors use and which determine how they process information and what information they consider relevant. 20 These models can clearly change rapidly, due to changing risk tolerance, market confidence and fads. Indeed, we do not understand how information about emerging markets is actually used by fund managers in their investment decisions. Perceptions of risk cannot reliably be based on econometric analysis of past trends, due to both the lack of data and frequent structural breaks. So asset valuation methods and portfolio composition rules used by investors in practice tend to be rather crude, being largely based on considerations of liquidity and exit possibilities (Clark et al. 1993) - both of which are difficult to estimate and subject to sudden shocks. Further, the incentives faced by fund managers themselves (such as quarterly performance bonuses based on performance relative to the industry average) are widely considered to exacerbate herding behaviour 21 , which in turn clearly exacerbates asset demand cycles. In addition, the risk aversion (or 'risk appetite' or 'risk tolerance') of

18 Default can arise for three reasons: insolvency (in the sense of insufficient trade surpluses to pay back debt); illiquidity (insufficient reserves for present debt service); and unwillingness to pay, or debt repudiation (when the cost-benefit of so doing merits it). See FitzGerald (2001c).

19 The ratio of central bank reserves to short-term external debt.

20 A good example of this is that maturity and currency mismatches in the balance sheets of Asian private banks were well known to both investors and regulators before the 1997-98 collapse, but simply not considered relevant to risk assessment.

21 Herding can be attributed to an externality where the payoff to an agent adopting an action is positively related to the number of agents adopting the same action; to principle-agent considerations where, in order to maintain or gain reputation when markets are imperfectly informed, a fund manager may 'hide in the herd' to avoid evaluation or 'ride the herd' to improve their reputation; and 'information cascades' where agents infer information from the actions of prior agents and optimally decide to ignore their own information (Devenow and Welck 1996). 
international investors varies enormously over comparatively short periods of timereflected in the ratio 22 of bond spreads to the volatility of returns, as Figure 5 indicates.

Figure 5: Global risk aversion

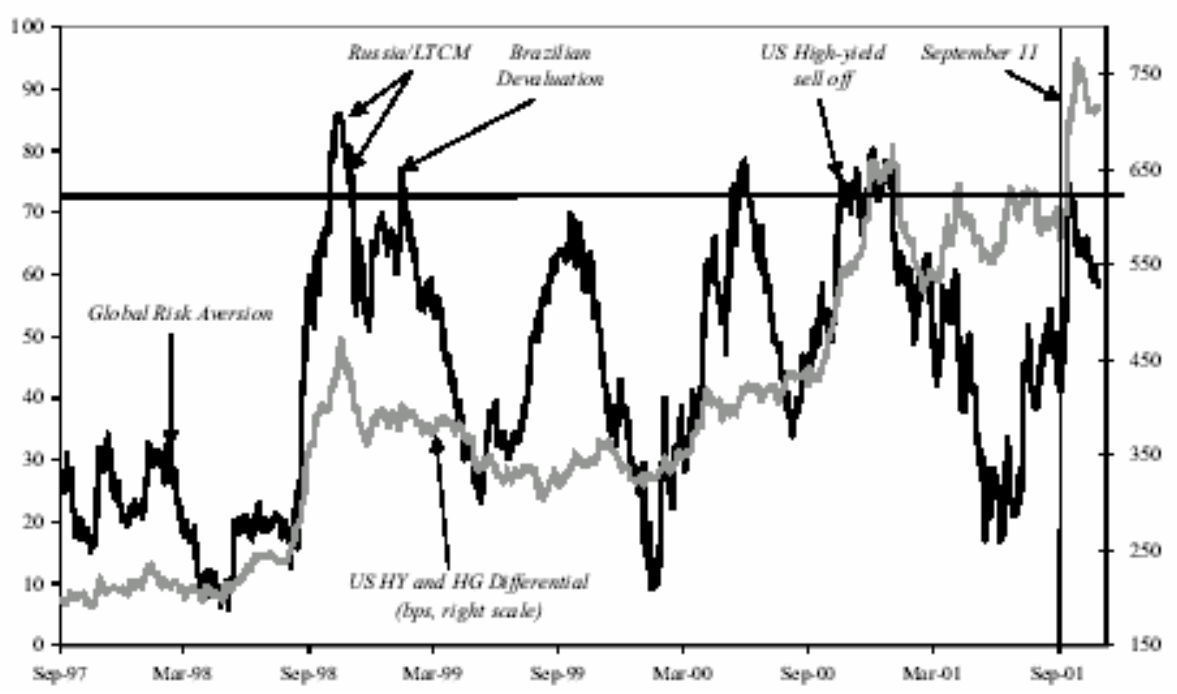

Source: J.P. Morgan (for the risk aversion index the LCPI is used).

This volatility has even wider implications for development economics. Variable risk aversion is a serious difficulty for conventional economic theory because the proposition that the underlying utility function can be inferred from the financial market via the mean-variance portfolio model is a basic tenet of neoclassical economics (Levy and Markowitz 1979). The key characteristic of the CRRA and similar utility functions is that the parameter $\gamma$ must not only be constant (as it reflects basic household tastes) and also be fairly low to be consistent with other results, such as distributive fiscal. 23

This is no surprise from a Keynesian point of view, where uncertainty cannot be reduced to probability, but rather is related to the strength or degree of belief and where investors are strongly influenced by 'animal spirits' and 'beauty contests' that lead to wild swings in these beliefs. In terms of the psychology of decision making 'people evaluate the probability of events by the degree to which these events are representative of the relevant model or process' and perceptions of risk under circumstances that are difficult to imagine or have not been experienced before are systematically underestimated, while by extension the probability of recurrence of recent major events (particularly if themselves unexpected) is overestimated (Kahneman et al. 1982: 97). Indeed, 'the idea that economic agents compute a future exchange rate based on a model they believe in, then telescope it back into the present, is of little use in a world where

22 Conventionally known as the Sharpe Ratio.

23 Formally $U\left(C_{t}\right)=\frac{C_{t}^{\gamma-1}-1}{1-\gamma}$ where $\gamma \neq 1, \gamma>0$ and $U\left(C_{t}\right)=\ln C_{t}$ where $\gamma=1$. Conventionally, $\gamma$ is assumed to lie between unity (risk neutrality) and 3 . 
economic agents have great difficulty in working out what the true model of the world is' (de Grauwe 1996: 189). Further, international financial markets become 'a breeding ground for fads which, in the absence of credible alternatives, are elevated to important theories' (ibid.: 202). There is thus a strong argument for emerging market authorities to adopt a counter-cyclical monetary stance in response to capital flows. This would involve real exchange rate targeting, bank credit regulation and an active fiscal stance and can be shown effective in supporting growth and investment (FitzGerald 2005b). In consequence, it is not surprising that most host governments have had to intervene (in many cases disguised as fiscal or regulatory measures) in the market in order to reduce the volatility of capital flows (FitzGerald 2005a). These controls are now usually based on price measures, particularly taxes, while quantitative instruments have become less common. Open-market operations have also proved quite successful in this regard, and can be complemented by the active use of reserve requirements and public sector deposits. Domestic regulatory systems for banks and securities markets (including corporate borrowing abroad) are also important supportive instruments.

However the integrated nature of world capital markets means that these measures can only have a limited effect. Public intervention - by the IMF itself or by a consortium of G3 central banks - could do a great deal to reduce the externality caused by fluctuating G3 demand for emerging market assets. I do not wish to suggest that fundamentals are unimportant; but which fundamentals are considered relevant and in what way depend on home investors, not host governments. On a parallel with traditional central bank intervention in advanced economies, they could conduct open market operations in these bonds in order to stabilise their price, and by acting as 'market makers' would encourage more home investors to enter the market. In particular, pension funds could benefit far more than they do at present from the high yields on these assets over the long run. It is of interest in this context that the Asian central banks are engaged in building a joint system of this kind based on their foreign exchange reserves built up as a crude insurance against financial crisis; but this does not address the root cause of asset demand instability.

In short, in a global economy development economists should pay far more attention to the consequences for emerging market countries of financial policies within and between advanced economies. There are major issues here for the future of development economics, which has yet to adequately address the issues raised by the externalities from international capital markets, the implications of volatile risk tolerance by international investors, and the adequacy of existing international institutions to cope with them. In recent years there have been considerable advances in this respect by trade economists concerned with the impact of global trade systems on growth and poverty in developing countries - in both the theoretical, empirical and policy dimensions - but there has been much less progress made by those working on international finance. 


\section{Technical Appendix}

\section{The efficient investor portfolio with EM assets}

Consider a world with two markets and two risky assets: 'home' $(h)$ and the host emerging market $(f)$. Home investors have access to both assets. Let $x^{f}$ be the home investor's share of portfolio wealth held in the host asset, and therefore $1-x^{f}$ be the share held in the domestic asset. Their objective function is given by

$V=V\left(E_{t} W_{t+1}, \operatorname{Var}\left(W_{t+1}\right)\right)$, where $V_{1} \succ 0$ and $V_{2} \prec 0$

Where $W_{t}$ is real wealth at time $t, E_{t}$ is the expectations operator conditional upon information at time $t$ and $V a r$ is the variance-covariance matrix operator. The investors' objective function is increasing in the mean of wealth but decreasing in its variability. They maximize (A.1) with respect to the vector of portfolio shares, $\underline{x}_{t} \equiv\left(x^{h}, x^{f}\right)^{\prime}$ where $x^{h}+x^{f}=1$. We define the return vector as $\underline{r}_{+} \equiv\left(\mathrm{r}_{\mathrm{t}}^{\mathrm{h}}, \mathrm{r}_{\mathrm{t}}^{\mathrm{f}}\right)^{\prime}$. Then the mean and variance of wealth can be written as

$E_{t} W_{t+1}=W_{t}\left(1+\underline{x}_{t}^{\prime} E_{t} \underline{r}_{t+1}\right)$

$\operatorname{Var}\left(W_{t+1}\right)=W_{t}^{2} \operatorname{Var}\left(\underline{x}_{t}^{\prime} \underline{r}_{t+1}\right)=W_{t}^{2} \underline{x}_{t}^{\prime} \operatorname{Var}\left(\underline{r}_{t+1}\right) \underline{x}_{t}$

Substituting $E_{t} W_{t+1}$ and $\operatorname{Var}\left(W_{t+1}\right)$ into (A.1) and maximizing the resulting expression with respect to $\underline{x}_{t}$ gives the first order condition for the efficient portfolio

$$
x_{t}^{f}=\frac{\left(E_{t} r_{t+1}^{f}-E_{t} r_{t+1}^{h}\right) / \gamma}{\operatorname{Var}\left(r^{f}-r^{h}\right)}+\frac{\sigma_{h}^{2}-\sigma_{h f}}{\operatorname{Var}\left(r^{f}-r^{h}\right)}
$$

where $\gamma$ is the parameter of relative risk aversion $\left(-2 V_{2} W_{t} / V_{1}\right), \sigma_{h}^{2}$ is the variance of the home asset returns, $\sigma_{f}^{2}$ is the variance of the EM asset returns and $\sigma_{h f}$ is the covariance between home and host returns.

Finally, home bias $(h)$ is then the difference between the EM share in the efficient portfolio and in the observed portfolio $(y)$

$$
h_{t}=x_{t}^{f}-y_{t}^{f}
$$




\section{Estimating the asset demand function}

A new method for joint estimation of bond flows and yield is based on this twoequation reduced form model; and tested on monthly data for US bond purchases, using the 'general to specific approach' (GETS) to find significant variables, lags, and shock dummies for yield spread and bond flows separately; followed by a 'full information maximum likelihood' (FIML) estimation of the two equations together. The results shown in Table A.1 are robust and give a very good fit for both yields and flows (see Figure A.1), confirming the predictions of the theoretical model.

Table A.1: FIML simultaneous estimates of EM bond flow and yield

Flow determinants:

$$
\begin{aligned}
& L T B D C_{t}^{\wedge}=+\underset{(0.059)}{0.596} L_{T B D C} C_{t-1}-\underset{(0.011)}{0.0475} \text { Spread }_{-} E M_{t}+\underset{(0.555)}{3.62}+\underset{(0.048)}{0.163 D L I I P_{t}} \\
& -\underset{(0.068)}{0.222 \text { FedFunds }_{t}}+\underset{(0.074)}{0.304 \text { FedFunds }_{t-2}}-\underset{(0.054)}{0.138 \text { DSpread }_{-} H Y_{t-2}}
\end{aligned}
$$

Yield determinants:

$$
\begin{aligned}
\text { Spread } E M_{t}^{\wedge}= & +\underset{(2.804)(0.046)}{6.44}+0.836 \text { Spread } E M_{t-1}-\underset{(0.278)}{0.561 \text { LTBDC }_{t}} \\
+ & 0.656 \text { DSpread }_{-} H Y_{t}+\underset{(1.021)}{7.48 I 1998: 8_{t}} \\
& (0.244)
\end{aligned}
$$

Source: FitzGerald and Krolzig (2003, 2005a).

Notes: Definitions: log of monthly flows (LTBDC), EMBI spread (Spread_EM), change in US industrial output (DIIP), Federal Funds Rate (FedFunds), change in US high-yield spread (Dspread_HY). Adjusted $\mathrm{R}^{2}$ for flows is $85 \%$, for spreads $88 \%$.

Figure A.1: Observed and fitted trends for bond flows

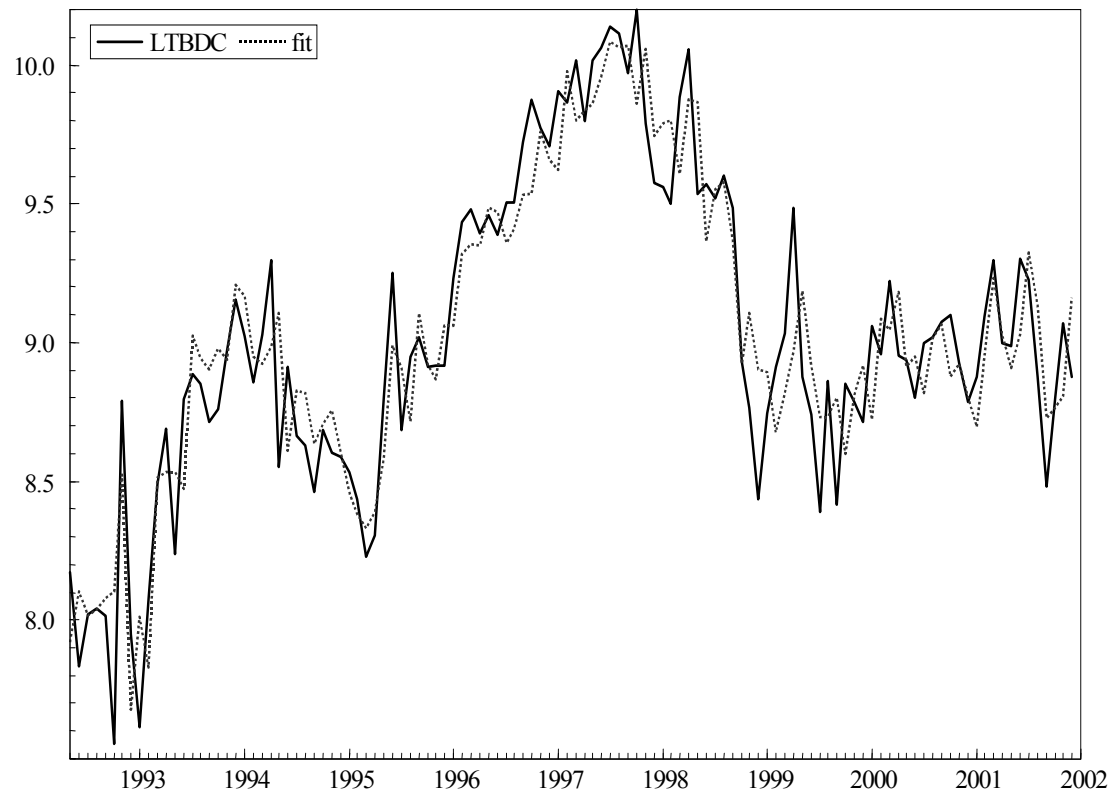




\section{The backward-sloping demand curve for international bank loans to EMs}

This function can be derived as follows. The lenders asset demand $\left(A_{d}\right)$ schedule is similar to that in equation (1) above except that now the return $\left(r_{f}\right)$ is the going interest rate spread $\left(i_{f}\right)$ over the home riskless asset, net of the probability of default $\left(p_{f}\right)$ adjusted for risk aversion $(\gamma)$, and the probability of default is proportional to the square of the interest rate charged. This yields a relationship between asset demand and the interest rate of quadratic form that is depicted in Figure 3

$$
\begin{aligned}
& A_{d}=a r_{f} \\
& r_{f}=i_{f}-\not p_{f} \\
& p_{f}=b i_{f}^{2} \\
& A_{d}=a i_{f}-b \dot{\gamma}_{f}^{2}
\end{aligned}
$$

As in Folkerts-Landau (1985) banks are assumed to attempt to compete for market shares, so that bank lending - that is, asset demand - is maximized at the equilibrium $\left(\bar{A}_{d}\right)$. This then corresponds to the point where

$$
\begin{aligned}
& \frac{\partial A_{d}}{\partial i_{f}}=a-2 b i_{f}=0 \\
& \bar{A}_{d}=\frac{a^{2}}{4 b \gamma}
\end{aligned}
$$

As $\gamma$ enters directly into this result, a decrease (increase) in investor risk version will lead to a rise (fall) in EM asset holdings and thus capital inflows (outflows).

There is no reason why this equilibrium point should coincide with the point of intersection of the asset demand schedule $\left(A_{d}\right)$ with the asset supply schedule $\left(A_{s}\right)$ except by coincidence. Of course, asset supply could be less than demand at this point, but this is not empirically plausible for EMs as an asset class (although it may be true of individual EMs in specific periods): so we may safely assume that in general $A_{s}>A_{d}$ at equilibrium. In other words, that the demand for loans on the part of EMs exceeds the supply of loans by the banks, and thus that the market does not clear and capital rationing exists.

\section{Capital flows, the real exchange rate and income distribution}

As an alternative to the main text, consider the case where the host economy adsorbs all the flow into the exchange rate so as to maintain the target output level $\left(Q^{*}\right)$ 
$e=\frac{m_{1} Q^{*}-F-x_{1} Z}{x_{2}+m_{2}}$

$\partial e / \partial F=-1 /\left(x_{2}+m_{2}\right)>0$

in which case increased capital inflows cause the real exchange rate to appreciate, outflows lead to a depreciation. To visualize the impact of capital flows on income distribution, consider a Dornbusch-type economy with two goods and their corresponding prices foreign $\left(P_{f}\right)$ and domestic $\left(P_{d}\right)$, then

$e=\frac{E P^{*}}{P}$

and the real wage rate $(\omega)$ is expressed in terms of the nominal wage $(w)$ and the consumer price level $\left(P_{w}\right)$, which depends in turn on the proportion $(\theta)$ of the domestic good in the consumption basket

$$
\begin{aligned}
& \omega=\frac{w}{P_{w}} \\
& p=\theta P+(1-\theta) E P^{*}
\end{aligned}
$$

Finally, the price of the non-traded domestic good $\left(P_{d}\right)$ is proportional to the nominal wage rate $(w)$

$$
P_{d}=\beta w
$$

We can now combine these, substituting (A.9) and (A.12) into (A.11) and then plugging the result into (A.10), so as to derive the link between the real exchange rate $(e)$ and the real wage rate $(\omega)$, and thus the impact of capital flows $(F)$ from (A.8)

$$
\begin{aligned}
& \begin{aligned}
\begin{array}{l}
\omega \\
\end{array} & {[\beta\{\theta+(1-\theta) e\}]^{-1} } \\
& =\left[\beta\left\{\theta+(1-\theta) \frac{m_{1} Q^{*}-F-x_{1} Z}{x_{2}+m_{2}}\right\}\right]^{-1}
\end{aligned} \\
& \frac{\partial \omega}{\partial F}>0
\end{aligned}
$$




\section{References}

Ahearne, A.G., W.L. Griever, and F. Warnock (2001). 'Information Costs and Home Bias: An Analysis of US Holdings of Foreign Equities', International Finance Discussion Papers 691, Board of Governors of the Federal Reserve System: Washington DC.

Atkinson, B.A., and J.E. Stiglitz (1980). Lectures in Public Economics, McGraw Hill: London.

Babilis, S., and V. FitzGerald (2005). 'Risk Tolerance, Home Bias and the Unstable Demand for Emerging Market Assets', International Review of Applied Economics 19(4): 459-76.

Bekaert, G., and C.R. Harvey (2000). 'Foreign Speculators and Emerging Equity Markets', Journal of Finance 55(2): 565-613.

Blake, D., and A. Timmermann (2000). 'International Investment Performance: Evidence From Institutional Investors' Foreign Equity Holdings', Pensions Institute Discussion Paper PI-0008, Birkbeck College: London.

Blake, D., B. Lehmann, and A. Timmermann (1999). 'Asset Allocation Dynamics and Pension Fund Performance', Journal of Business 72: 429-61.

Chuhan, P., S. Claessens, and N. Mamingi (1998). 'Equity and Bond Flows to Latin America and Asia: The Role of Global and Country Factors', Journal of Development Economics 55: 439-63.

Clark E., M. Levasseu, and P. Rousseau (1993). International Finance, Chapman and Hall: London.

Cooper, I., and E. Kaplanis (1994). 'Home Bias in Equity Portfolios, Inflation Hedging and International Capital Market Equilibrium', Review of Financial Studies 7(1): 4560 .

de Grauwe, P. (1996). International Money, Oxford University Press: Oxford.

Devenow, A, and I. Welck (1996). 'Rational Herding in Financial Economics' European Economic Review 40: 603-15.

Disyatat, P., and R.G. Gelos (2001). 'The Asset Allocation of Emerging Market Funds', IMF Working Papers 01/11, International Monetary Fund: Washington DC.

Dumas, B. (1994). 'Partial Equilibrium Versus General Equilibrium Models Of The International Capital Market', in F van der Ploeg (ed.) The Handbook of International Macroeconomics, Blackwell: Oxford.

Fernández-Arias E. (1996). 'The New Wave of Private Capital Inflows: Push or Pull?', Journal of Development Economics 48(2): 389-418. 
FitzGerald, V. (2001a). 'Short-Term Capital Flows, The Real Economy and Income Distribution in Developing Countries', in S. Griffith-Jones, M. Montes, and A. Nasution (eds) Short-term Capital Flows and Economic Crises, Oxford University Press for UNU-WIDER: Oxford.

FitzGerald, V. (2001b). 'Financial Globalization and Child Wellbeing', Florence UNICEF at www.unicef-icdc.org/research/; also as Oxford University QEH Working Papers 77, Queen Elizabeth House: Oxford.

FitzGerald, V. (2001c). 'Developing Countries and Multilateral Investment Negotiations', in E.C. Nieuwenhuys and M.M.T.A. Brus (eds) Multilateral Regulation of Investment, Kluwer Law International: The Hague.

FitzGerald, V. (2003). 'The Instability of International Demand for Emerging Market Assets', in R. Ffrench-Davis and S. Griffith-Jones (eds) From Capital Surges to Drought: Seeking Stability for Developing Economies, Palgrave Macmillan for UNU-WIDER: Basingstoke.

FitzGerald, V. (2005a). 'Policy Issues in Market Based and Non-Market Based Measures to Control the Volatility of Portfolio Investment', in C.J. Green, C. Kirkpatrick, and V. Murinde (eds) Finance and Development: Surveys of theory, Evidence and Policy, Edward Elgar: Aldershot.

FitzGerald, V. (2005b). 'Monetary Models and Inflation Targeting in Emerging Market Economies', in P. Arestis, J. McCombie, and M. Baddeley (eds) The New Monetary Policy, Edward Elgar: Cheltenham.

FitzGerald, V., and D. Krolzig (2003, 2005a). 'Modelling the Demand for Emerging Market Assets', Financial Economics Working Papers 2003-FE-10, Said Business School: Oxford. Revised version presented at the 2005 Emerging Markets Finance Conference at the Cass Business School, 5 May, London; available on www.cass.city.ac.uk/emg/seminars/ Papers/Fitzgerald_Krolzig.pdf.

FitzGerald, V., and D. Krolzig (2005b). 'The Simultaneous Determination of Emerging Markets Bond Flows and Yield Spreads', Financial Economics Working Papers 2005-FE-15, Said Business School: Oxford.

FitzGerald, V., and G. Perosino (1999). 'Trade Liberalization, Employment and Wages: A Critical Approach', in G. Barba-Navarretti, R. Faini, and G. Zanalada (eds) Labour Markets, Poverty and Development, Clarendon: Oxford.

Folkerts-Landau, D. (1985). 'The Changing Role of International Bank Lending in Development Finance', IMF Staff Papers 32: 317-363.

French, K.R., and J.M. Poterba (1991). 'International Diversification and International Equity Markets', American Economic Review 81(2): 222-6. 
Froot, K.A., and P.G.J. O'Connell (2003). 'The Risk Tolerance of International Investors', NBER Working Papers 10157, National Bureau of Economic Research: Cambridge MA.

Grinblatt, M., and M. Keloharju (2000). 'The Investment Behaviour and Performance of Various Investor Types: A Study of Finland's Unique Dataset', Journal of Financial Economics 55: 43-67.

Henry, P.B. (2000). 'Stock Market Liberalization, Economic Reform and Emerging Market Equity Prices', Journal of Finance 55(2): 529-64.

Klein, R., and V. Bawa (1977). 'The Effect of Estimation Risk on Optimal Portfolio Choice', Journal of Financial Economics 3: 215-31.

IMF (2001). Emerging Market Financing, International Monetary Fund: Washington DC.

IMF (2005). Global Financial Stability Report, International Monetary Fund: Washington DC.

Jeanneau, S., and M. Micu (2002). 'Determinants of International Bank Lending to Emerging Market Countries', BIS Working Papers 112, Bank for International Settlements: Basle.

Kahneman, D., P. Slovic, and A. Tversky (1982). Judgement Under Uncertainty: Heuristics and Biases, Cambridge University Press: Cambridge.

Karolyi, G.A., and R.M. Stulz (2002). 'Are Financial Assets Priced Locally or Globally?', NBER Working Paper 8994, National Bureau of Economic Research: Cambridge MA.

Kumar, M.S., and A. Persaud (2001). 'Pure Contagion and Investors' Shifting Risk Tolerance: Analytical Issues and Empirical Evidence', IMF Working Papers 01/134, International Monetary Fund: Washington DC.

Levy, H., and H.M. Markowitz (1979). 'Approximating Expected Utility by a Function of Mean and Variance', American Economic Review 69: 308-17.

Lewis, K. (1999). 'Trying to Explain Home Bias in Equities and Consumption', Journal of Economic Literature 37(2): 571-608.

Mody, A., and M.P. Taylor (2002). 'International Capital Crunches: The Time-Varying Role of Informational Asymmetries', IMF Working Papers 02/43, International Monetary Fund: Washington DC.

Mody, A., M.P. Taylor, and J.Y. Kim (2001). 'Modelling Fundamentals for Forecasting Capital Flows to Emerging Markets', International Journal of Finance and Economics 6: 201-16. 
Montiel, P., and C.M. Reinhart (1999). 'Do Capital Controls and Macroeconomic Policies Influence the Volume and Composition of Capital Flows? Evidence from the 1990s', Journal of International Money and Finance 18: 619-35.

Montiel, P., and C.M. Reinhart (2001). 'The Dynamics of Capital Movements in Emerging Economies During the 1990s', in S. Griffith-Jones, M.F. Montes, and A. Nasution (eds) Short-term Capital Flows and Economic Crises, Oxford University Press for UNU-WIDER: Oxford.

Obstfeld, M., and K. Rogoff (1996). Foundations of International Macroeconomics, IT Press: London.

Siegmann, A. (2003). 'Optimal Investment Policies for Defined Benefit Pension Funds', Research Memoranda 728/0308, Netherlands Central Bank: Amsterdam.

Taylor, M.P., and L. Sarno, (1997). 'Capital Flows to Developing Countries: Long- and Short-Term Determinants’, World Bank Economic Review 11(3): 451-70.

Tesar, L., and I. Werner (1995). 'Home Bias and High Turnover', Journal of International Money and Finance 14(4): 467-92. 